\title{
Apathy, adaptation or ethnic mobilisation? On the attitudes of a politically excluded group
}

\section{Claudia Diehl and Michael Blohm}

Abstract This paper examines political attitudes and behavioural intentions of immigrants in the field of voting behaviour. Based on a quantitative survey of the population of Turkish origin in Mannheim, Germany, and data from the German Socio-Economic Panel (GSOEP), we show that the political attitudes of immigrants reflect their marginal legal status: immigrants show a lower interest in the political processes of the host country and a lower identification with its political institutions than natives, and this difference is only partly explained by immigrants' lower socio-economic status. Alienation from institutions in the host country increases migrants' likelihood of considering ethnically segregated immigrant parties as more suitable for representing their interests than the political parties of the host country. A closer look at the political attitudes of these supporters of immigrant parties reveals, however, little evidence of collective interest formation among this group.

KeYWORDS: Political PARTICIPATION; IMMigRATION; GERMANY; ETHNIC POLITICS

\section{Introduction}

In general, political debates about immigration and political representation offer ample opportunities to study the relationship between immigrants and the receiving country. The debate about reforming citizenship law in Germany after the coalition of Social Democrats and the Green Party entered the government in late 1998 is one such case. Although this debate was partially driven by the growing consensus that immigrants' access to political participation should be improved, it also gave students of this debate the impression that increased access to political participation might cause a far more serious problem than political exclusion. The debate reached its peak when conservatives who were against the reform alleged that its supporters merely had a strategic interest in the immigrant vote. They went so far as to call the reform of citizenship law 'electoral fraud for Germans' (Süddeutsche Zeitung, 23 September 1998). In response, supporters of the reform countered that conservatives opposed the reform because they knew that they could not expect to gain any political advantage if immigrants were given increased access to the political process.

A group that remained remarkably silent during this debate was the immigrants themselves. Considering their political attitudes more thoroughly would have been revealing, however: one of the few analyses based on reliable data showed that only a minority of immigrants has a preference for a German political party at all (Diehl and Urbahn 1998). Low political interest is one of the consistent findings in surveys of immigrants in Germany. In a survey 
we conducted among Turkish immigrants in Mannheim, for example, half of the respondents claimed that their interests might be advocated more efficiently by voting for special 'immigrant' parties than by voting for parties of the host country (we shall describe this survey in more detail later). Although there is only a loose correlation between attitudes and behaviour, especially when attitudes refer to behaviour that does not yet have relevance in everyday life, this example shows how a large gap can exist between ideas and empirical findings in the field of immigrant political participation.

In this paper we aim to close this gap by addressing the following questions. Which patterns of participation will 'labour migrants' and their descendants living in Germany most likely show when participation opportunities increase? How can these patterns be explained? Are they caused simply by migrants' lower socio-economic status, do they reflect their marginal legal status, or are they influenced by group-level factors such as their sector of association?

In our analysis we pay special attention to the political attitudes and behavioural intentions of Turkish immigrants in Germany with regard to voting. ${ }^{1}$ In studying future patterns of immigrant voting, analysis must necessarily be indirect, focusing on factors known to influence it, such as political interest and party preference. Although it would be interesting to study the voting behaviour of naturalised migrants as a further indicator, this is difficult for methodological reasons: once immigrants naturalise they cannot be identified as such in most population surveys. Due to this problem and the fact that naturalised labour migrants are still a small group, it requires a time- and money-consuming screening procedure to study their voting behaviour (see Wüst 2000). In addition, migrants holding Turkish nationality are not entitled to vote at the local level. Thus, studies similar to those done in the Netherlands (Bukow 1989; Koolen 1999; Tillie 1998) about the voting behaviour of migrants cannot be used to provide additional evidence on the issue. Given its restrictive citizenship law, however, the German case is particularly suited to studying the political attitudes of migrants, which are formed within the context of formal political exclusion.

Our paper consists of the following sequences. First we present the theoretical background for our research by identifying those factors that have been shown to influence migrants' political participation in the field of voting. We then discuss the status quo in Germany with regard to the relevant factors. We then proceed to assess the likely reaction of immigrants to increasing opportunities for participation. In doing so, we distinguish between three possible reactions: 'adaptation' to the participation patterns of the majority, political apathy, or the emergence of an ethnically segregated lobby. The paper concludes with a summary and a discussion of our findings.

\section{Theoretical background: determinants of immigrant participation}

Our theoretical approach is grounded in prior research on the determinants of immigrants' voting behaviour. Many studies have sought to identify factors that influence the degree and nature of voting behaviour, both for people in general and migrants in particular. In countries that have granted voting rights to migrants, studies show that the extent to which migrants make use of these rights (and the way that they do so) varies considerably both within and between ethnic groups (Fennema and Tillie 1999; Koolen 1999; Tillie 1998; Togeby 1999). The relevant determinants of voting behaviour identified so far 
can be divided roughly into three groups: macro-level factors, most importantly the institutional and political setting in which participation takes place; meso-level factors, such as the nature of an ethnic group's internal integration; and microlevel factors, basically individual traits and characteristics.

\section{Macro-level determinants}

Without explicit reference to voting behaviour, proponents of an institutionalist approach have shown that immigrants' political participation is influenced by national or supranational political institutions that shape the political opportunity structure (Ireland 1994, 2000; Koopmans and Statham 1999; Soysal 1994; Statham 1999). Patrick Ireland first and most explicitly linked political opportunity structures to migrants' participation. His institutionalist approach is the most fully elaborated theoretical schema to date in the field of migrant participation. According to Ireland, his 'institutional channelling approach' constitutes a third explanatory approach alongside 'class theory' and 'ethnicity/race theory' to explain immigrant political participation (Ireland 1994: 5). Whereas Ireland stresses the role of national institutions in shaping migrant participation, others (notably Soysal 1994) argue that supranational institutions play an increasingly important role. The most important feature of the political opportunity structure with regard to migrant voting behaviour is, of course, whether they enjoy voting rights and have easy access to citizenship, thus enabling them to become full members of the political community.

Besides directly determining how much voice immigrants have in the host society, prior research also suggests that institutional features have an indirect effect on migrant involvement in political affairs. One important mediating factor is the likelihood of success that people attribute to political engagement. Activists are known to overestimate the effect of their contributions (Finkel and Muller 1998; Finkel et al. 1989). This cognitive 'trick' is hard to manage for people who are disenfranchised and thus cannot exert political pressure by making credible threats of bloc voting. The latter strategy is of crucial importance when it comes to the political mobilisation of ascriptive groups such as women, the elderly, or blacks (Dentler 1995; Mueller 1988). A lack of voting rights thus yields a long-term demobilisation of immigrants beyond their mere inability to cast a ballot. Though empirical evidence from countries where voting rights have been granted to migrants is rare and rather unsystematic, it none the less reveals a tendency for migrants to have a lower turnout than the majority population, even though there are exceptions to this pattern (as we shall see below). This raises the question whether this political 'demobilisation' reflects group differences in individual factors known to enhance participation (such as education) or their macro-level political exclusion.

In addition, institutional factors not only affect if migrants become politically involved, but also how they do. They influence, for instance, the incentives and opportunities for migrants to promote group formation and campaigning within or across ethnic lines (see Statham 1999). In doing so, they shape the nature and strength of ethnic cleavages underlying a migrant group's voting behaviour - a point that will be elaborated later - as well as the likelihood and success of organising ethnically based interests once migrants do become entitled to vote. National institutions also affect the opportunity structure for successful nomination of ethnic candidates and the founding of immigrant parties. However, 
these factors can only partially explain the turn-out rates and the party choices made by migrants since they cannot explain any variance within an institutional setting. Numerous studies have shown that voting behaviour in general and migrants' voting behaviour in particular are also very heavily influenced by individual- and group-level factors.

\section{Micro- and meso-level determinants}

The Civic Voluntarism Model of political participation provides a sound theoretical and substantive account of the relationship between people's personal traits and their political participation (Brady et al. 1995; Verba et al. 1995). According to this model, the central factors influencing political engagement are found in behavioural resources relevant to participation, such as time, money, and civic skills, and in personal predispositions such as political interest, personal belief in one's own political efficiency, and access to recruitment networks. This perspective assumes a positive correlation between available resources and an actor's willingness to participate politically. Civic skills, in particular, are mediated by people's socio-economic background (and by their non-political affiliations) thereby increasing both their willingness and opportunity to become politically active.

Proponents of the Civic Voluntarism Model assume that belonging to a certain ethnic group - operationalised by ethnic group consciousness, experiences of discrimination and perceptions of commonly shared problems - has no independent influence on the extent of political participation once one controls for resource endowments and other conditions of participation (Verba et al. 1995: 355). Since minorities often possess fewer resources than the majority, one can generally expect them to be a 'demobilised' group.

None the less, a lack of resources neither automatically nor necessarily leads to demobilisation (and thus low turn-out rates). There is evidence that Turkish migrants have occasionally (and considered from a resource approach, unexpectedly) achieved turn-out rates equal to or exceeding natives (Fennema and Tillie 1999: 709; Togeby 1999: 673). These studies suggest that high turn-out rates and political interest in host-country institutions are positively linked to a group's degree of internal integration, as manifested in the number of ethnic associations (among other indicators). 'Group based or collective political mobilisation [...] is usually sustained through strong organisations. [...] Collective mobilisation explains why some groups, despite few individual resources, manage a high level of participation' (Togeby 1999: 667).

From a social capital perspective, however, affiliations with voluntary associations are generally assumed to relate positively to political participation independent of their ethnic composition (Putnam 2000: 338). This argument relies on an earlier idea of Verba, who claimed that institutional affiliations are especially influential in mobilising people to vote (Verba 1978: 119). The assumed mechanisms behind voluntary group affiliations are fourfold: associations mobilise members explicitly; they expose them to stimuli such as political discussions; they provide opportunities to be active; and, finally, they control specific channels of participation (Verba 1978: 81; for a different enumeration see Putnam 2000: 338-9).

Institutionalist approaches of immigrant participation have been criticised for 
explanatory shortcomings on similar grounds. Bousetta argues, for example, that they overemphasise the role of political institutions in explaining migrants' participation by neglecting 'the infra-political dimensions of ethnic processes' such as 'the whole bulk of political action acted offstage by individuals and groups within immigrant minority communities' (Bousetta 2000: 237, 243). In accordance with findings mentioned above, Bousetta claims that these play an independent role in shaping migrants' participation and are overlooked when focusing exclusively on the broader political setting. Tillie (1998) likewise argues that migrants can vote either according to their broader ideological and partisan affiliations, or according to group belonging and related issues.

Cleavage voting of migrants may either be ethnically based or anti-racist in nature (Cadat and Fennema 1996; Tillie 1998). While ethnically based participation aims primarily at preserving the cultural identity of an immigrant group, anti-racist participation is focused on achieving equal rights and opportunities for minority and majority members. Migrants display ethnically based participation patterns if they support political measures in favour of preserving their own group as a culturally, religiously and/or linguistically distinct unity. This orientation is often articulated in the form of political demands for 'minority rights' (granting the group better opportunities to pursue and maintain cultural characteristics relating to language, food and dress). In contrast, universalistic interests of ethnic groups are expressed as demands for 'colour blindness' and civil rights which aim at eliminating formal and informal discrimination hindering immigrants from moving upwards in the receiving country's status systems. The latter interests are often shared by other structurally disadvantaged groups, regardless of whether or not they identify with the particular ethnic community (Sanders 1991).

Immigrants' political engagement in the host country is usually orientated either towards group maintenance or equal rights, a distinction that holds true for political associations, immigrant politicians (see Rath 1988: 274) and immigrant parties. The migrant parties that emerged in the Netherlands after immigrants were granted voting rights in 1985 were partly religious and partly anti-racist in character and on the whole received limited support (Bukow 1989: 109; Koolen 1999: 80).

Although the institutional environment of the host country influences which kind of cleavage dominates the infra-political mobilisation of migrants, it is only one set of several factors doing so. Many empirical studies have documented major differences in organisational patterns between and within different nationality groups (e.g. along gender lines) within the same institutional context. These studies show that migrant associations strongly reflect their members' educational endowments, their political and economic situations (Sassen-Koob 1979), the loss of status they encountered by migration (Jones-Correa 1998), the factors having caused their emigration, and so forth. These various factors produce considerable variance in patterns of immigrant participation (Portes and Rumbaut 1996: 130). They influence peoples' voting behaviour not only via the participatory resources different groups have at their disposal but also by influencing the nature of a group's infra-political mobilisation. This said, we now turn to our analysis of expected voting behaviour among migrants living in Germany and the degree to which it reflects the institutional, personal and group factors discussed above. 


\section{Database: the German socio-economic panel and a local study}

Our data are drawn from two surveys of immigrants living in Germany that included questions about social and political participation and political attitudes: the German Socio-Economic Panel (GSOEP) and a special survey conducted by the authors at the Mannheim Centre for European Social Research (MZES) among Turkish immigrants in Mannheim. The German Institute for Economy (DIW = Deutsches Institut für Wirtschaft) has conducted the GSOEP annually since 1984. To be included in the sample, interviewees had to live together in one household with a German or an immigrant head of household, and had to be at least 16 years old at the time of the survey. In addition, immigrants had to be 'guestworkers' who had migrated to Germany during the period of labour recruitment. For this reason, only those households having a Turkish, Spanish, Greek, Yugoslavian or Italian head were interviewed. The GSOEP survey thus does not represent the total foreign population of Germany with regard to ethnic composition. However, the nationalities of labour migrants represent, in numerical terms, the largest groups in the immigrant population. Our analysis is based on the 13th GSOEP - those who were interviewed in 1996.

Since the GSOEP only has limited information about the socio-political participation habits of immigrants, we draw on additional data from the 'Mannheim Participation Study' gathered as part of a larger research project ('Participation of Immigrants') funded by the German Science Foundation (DFG). The data come from a survey conducted in 1999 by the Mannheim Centre for European Social Research (MZES) on a random sample obtained from the city of Mannheim of 750 female and male Turks aged 16 and over. Respondents were interviewed face-to-face, by bilingual interviewers using a bilingual, standardised questionnaire. The response rate was fairly high and the sample differs only slightly from the GSOEP in terms of its age and gender distribution. The same holds true for the educational composition.

The Mannheim survey focused on participation in social and political voluntary organisations. Every respondent was asked whether and how often he or she visits different types of voluntary associations (religious, political, cultural, sports, union, educational, student/professional, others). In addition, questions about political orientations (preferences for German parties, attitudes about immigrant parties, political interest in German versus Turkish politics) were also asked, along with other items assessing attitudes toward citizenship and naturalisation. As will be elaborated later, we also tried to assess migrants' political orientations with regard to civil rights and minority issues. In order to gain additional information about the nature of the Turkish migrants' self-organisation and infra-political mobilisation, the Mannheim study also conducted a survey among Turkish clubs and organisations. The leaders of 41 Turkish associations that could be identified in Mannheim participated in a 1-2 hour semi-structured interview to report on the goals and activities of their groups.

\section{The status quo in Germany: the macro level}

Political participation among immigrants in Germany is constrained by a restrictive citizenship law and a lack of political rights for non-Germans. The famous and only recently abandoned declaration that 'Germany is not a country of immigration' ${ }^{2}$ still holds true when it comes to the legal conditions for political 
integration within Germany. Until recently, German citizenship law, the fundamental ideas of which date to 1912, stated that belonging to the German nation is a matter of descent and not of birthplace. The consequences are well known: while immigrants from Eastern European countries who can prove German descent can easily obtain German citizenship, most 'guestworkers' as well as their German-born children and grandchildren remain foreigners, even though the vast majority intend to stay in Germany permanently. ${ }^{3}$

One might argue, however, that citizenship is of secondary importance because the juridical condition of belonging to a nation has virtually no relevance in everyday life, as long as immigrants have secured legal residency and enjoy social, political and civic rights independently of their citizenship status. Although this might be plausible with regard to social and civic rights, Germans and non-Germans are none the less granted different political rights, at least partially. Foreigners, like Germans, enjoy rights that are granted to all persons, regardless of their citizenship status. They have the right to freely develop their personalities, the right to freedom from prejudice and discrimination based on descent, belief, or political views, the right to pursue religious beliefs undisturbed, and the right to freedom of speech - to name only the human rights granted in the constitution that are relevant to political participation.

Other rights directly influencing participation, such as the right of assembly and the right to establish unions and organisations, are granted by the constitution only to German citizens. These rights are the only 'participation rights' explicitly formulated in the constitution. There are no additional individual rights to political action for Germans or non-Germans. Some rights, such as the right to form associations, are not directly granted to non-Germans through the constitution, but by law. Immigrants are, for instance, allowed to declare their opinions in political matters; to take part in demonstrations, strikes, and leaflet actions; to belong to a party or trade union; to take part in the election of occupational organisations, schools and universities; and (in some towns) to play an advisory role in municipal decision-making (Bischoff and Teubner 1992: 91). Immigrants are, however, clearly restricted in their opportunities for participation when it comes to voting rights. Immigrants from countries that are not EU member states do not have the right to take part in elections at all, whereas immigrants from EU member states can participate in municipal and European elections.

There are basically two ways to increase opportunities for immigrant political participation. First, they could be increased by granting immigrants voting rights at the municipal level. Certainly, this opportunity became unrealistic in Germany after the Constitutional Court declared that the participation of immigrants in local elections was unconstitutional. The explanation for this decision was that there must not be a different basis for legitimising elections on the municipal, federal, and national levels (Mitglieder des Bundesverfassungsgerichts 1991). In Germany, this lack of voting rights is not counterbalanced by an alternative channel for participation by non-citizens. The so-called foreigner councils (Ausländerbeiräte) established during the years of guestworker immigration to allow immigrants to articulate their interests are widely considered as 'token institutions' without any political power.

The second way to improve immigrant political participation would be to grant easier access to citizenship. Even though citizenship has become easier to obtain over the last few years naturalisation rates have so far increased only 
Table 1. Application for naturalisation under different conditions (column per cent)

\begin{tabular}{|c|c|c|c|c|c|c|c|}
\hline & \multicolumn{4}{|c|}{ GSOEP 1996} & \multirow{2}{*}{\multicolumn{3}{|c|}{$\begin{array}{c}\text { Mannheim Participation Study } \\
\text { Turkish immigrants }\end{array}$}} \\
\hline & \multicolumn{2}{|c|}{ Immigrants total } & \multicolumn{2}{|c|}{ Turkish immigrants } & & & \\
\hline & $\begin{array}{c}\text { Only } \\
\text { one }\end{array}$ & Both & $\begin{array}{l}\text { Only } \\
\text { one }\end{array}$ & Both & $\begin{array}{c}\text { Only } \\
\text { one }\end{array}$ & Both & $\begin{array}{l}\text { Both but } \\
\text { limited }\end{array}$ \\
\hline Yes & 22.6 & 57.3 & 34.5 & 60.1 & 56.6 & 73.1 & 52.8 \\
\hline No & 77.4 & 42.7 & 65.5 & 39.9 & 43.4 & 26.9 & 47.2 \\
\hline$N$ & 1,912 & 1,913 & 769 & 768 & 678 & 681 & 664 \\
\hline
\end{tabular}

Sources: Mannheim Participation Study (1999); GSOEP (1996).

Note: Questions (GSOEP): (only one) ‘Do you intend to apply for German citizenship within the next 2 years?' (both) 'If it was possible to gain German citizenship in addition to your current citizenship, would you make use of such a possibility?' Questions (Mannheim Participation Study): (only one) 'If in the future you have to decide between German and Turkish citizenship, would you apply for German citizenship under these conditions?' (both) 'If in future you can gain dual citizenship would you apply for German citizenship within the next 2 years under this condition?' (time-limited) 'If you can gain dual citizenship in future, but you have to chose between them in 5 years, would you apply for German citizenship within the next 2 years under this condition?'

moderately, due primarily to the fact that, apart from special exceptions, dual citizenship is still forbidden. According to several surveys, the main reason why many immigrants hesitate to apply for German citizenship is the requirement that they renounce their old citizenship. As shown in Table 1, this finding is supported by the data from both the GSOEP and the Mannheim Participation Study. For a better comparison between the two studies, only the Turkish immigrants are presented as a separate group. The data show that in both studies, many interviewees admitted to wanting German citizenship but only if they could retain their former citizenship. The Turkish population of Mannheim shows a remarkably high readiness to naturalise even under the condition of a single citizenship policy. The figures indicate a potential increase in naturalisation rates in the near future.

In the 'Participation of Immigrants' research project additional data were collected on the acceptance of time-limited dual citizenship - a reform that was discussed in Germany in 1999 as an option even for adults. Taking into account that this is a hypothetical and thus methodologically problematic question, the answers can still be seen as an initial indicator that this reform would not have changed these figures: even fewer immigrants said that they would seek dual citizenship for a 5-year period than under a 'single citizenship only' rule. Given the fact that this survey was conducted while the time-limited dual citizenship was under discussion, however, it might well be that these findings reflect opposition to this reform, which many immigrants saw as too restrictive.

The reformed citizenship law that took effect on 1 January 2000 states that children of immigrants living in Germany will be granted both German citizenship and that of their parents' country of birth. Every child is entitled to citizenship as soon as one parent has lived in Germany for at least 8 years and possesses limited or unlimited permission to stay. Double citizenship, however, is a time-limited option. By the age of 23, each person must have decided which (single) citizenship he or she wants to retain. Moreover, the length of stay required for naturalisation has been reduced. Immigrants no longer have to 
live in Germany for 15 years to become eligible for citizenship, as was the case before the reform, but for just 8 years. According to an estimate by the commissioner for immigrants (Ausländerbeauftragte) in Berlin, about half of all immigrants living in Germany are presently entitled to naturalisation. ${ }^{4}$ Our own calculations based on data from the GSOEP indicate that the number of immigrants 16 and over who are entitled to naturalisation will increase by 5 per cent as a direct result of this reform. Although time will tell how the new regulations affect immigrants' readiness to obtain citizenship, we can nevertheless assume that the number of naturalisations will increase ${ }^{5}$ and that the numerical importance of new citizens will require an examination of the ways in which they begin to participate and orientate themselves politically. In general, however, one can conclude that, owing to a long-lasting lack of opportunities to participate in Germany's politics, migrants can be expected to remain rather alienated from its political institutions.

\section{The status quo in Germany: the micro and meso levels}

With regard to the individual factors that are generally known to promote peoples' interest and involvement in politics, the situation in Germany leads to a similar conclusion. Labour migrants control fewer resources for participation than do native persons with regard to education, occupation, shift work, and income. Especially for Turkish migrants these deficits decrease but do not vanish in the second generation (Alba et al. 1994; Bender and Seifert 2000; Szydlik 1996).

It was argued above that a lack of resources may be counterbalanced by strong group-based mobilisation. This raises the question of what characterises the internal integration of a group in terms of its strength and its nature. Looking at data from the Mannheim Participation Study, the first evidence is that Turkish migrants have lower levels of participation than Germans: 54 per cent of the German but only 39 per cent of the Turkish respondents were members of a voluntary association (data on membership of Germans comes from another survey conducted in Mannheim in 1999). Compared with other groups, however, Turkish migrants seem to have a fairly high participation rate. In a study where participation in ethnic clubs was measured for different groups of labour migrants, Turkish and Greek migrants displayed the highest membership rate in ethnic clubs (26 and 29 per cent). Unlike Greeks, however, Turkish migrants showed the lowest levels of association with German clubs - 14 per cent (Mehrländer et al. 1996: 331). The latter finding is in accordance with data from the Mannheim study, which show that participation takes place mostly in Turkish clubs. Only a minority (who are almost exclusively younger migrants) participate in associations with mostly German membership.

Even though a thorough analysis of the activities of Turkish clubs lies outside the scope of this paper, it is relevant that these clubs strongly reflect homeland identities and cleavages and have little to do with German political issues. For instance, among the 41 Turkish clubs participating in the survey, 27 offered religious or cultural activities relating to the home country. Moreover, despite the fact that half of the association leaders claimed to lobby for their members, the interviews revealed that most associations restricted their political lobbying to internal discussions or were strictly involved in homeland issues (see Diehl 2001). Since members of these groups are generally politically interested, however, they do discuss the political situation of migrants in Germany, which may 
itself promote an interest not only in Turkish but in German politics. Many leaders mentioned that informal discussions about the situation in Germany frequently took place within the club, although the actual activities of the organisation were directed towards the homeland.

Only eight clubs engaged in political lobbying activities in Germany on behalf of the migrants, and these were restricted mostly to lobbying for religious rights. Almost all the bigger mosques, for instance, issued statements about the topic of teaching Islam in German schools. Several religious clubs got involved in their members' struggles about the right to wear headscarves in school, or to let their daughters stay away from sports classes. An umbrella organisation pressured local authorities to allow women to wear headscarves on pictures for drivers' licences. All of these measures sought for migrants to make use of and preserve their homeland-specific cultural capital in the host society.

Only three clubs engaged in civil rights issues within Germany: a cultural centre of the Alevites, a civil rights group that is now frequented mostly by Turks but is multi-ethnic in focus, and a Turkish student club. One club did collect signatures for the introduction of double-citizenship at the time when the German Christian Democratic Party was gathering signatures against it. The latter two groups, especially, are typical associations of the second-generation 'educated elite'. In general, however, on a local level Turkish clubs have not developed into lobby groups for civil rights and against racism (for similar results see Koopmans and Statham 1999).

This brief review of factors known to influence migrant participation patterns reveals that the institutional setting in Germany as well as migrant resources act to demobilise political participation rather than promote it. Migrants control few of the resources that are generally known to enhance political mobilisation and the political opportunity structure tends to reinforce their alienation from German political institutions. Things look a bit different with regard to membership in voluntary organisations, however. Even though Turkish migrants participate less often than Germans, more than one in every three migrants is a member of some voluntary association. Although in theory this membership may counterbalance their lack of resources, the affiliations are mostly with Turkish associations and migrants' infra-political mobilisation is typically directed toward homeland issues. It thus remains an open question whether association membership promotes or weakens identification with German political institutions. One could well argue that the combination of restrictive participation opportunities in Germany and a well-developed self-organisation with a strong focus on the homeland provides a fertile ground for some sort of ethnically based mobilisation.

\section{Migrants' political attitudes and behavioural intentions}

We now analyse migrants' expected voting behaviour by investigating three possible outcomes: whether it is similar to that of Germans, characterised by apathy or, perhaps more likely, takes the form of ethnic cleavage voting. To generate indicators of participation patterns similar to those of the majority members, migrants' were asked about the strength and the nature of their identifications with and preferences for German parties. ${ }^{6}$ To indicate ethnic cleavage voting, we asked about attitudes toward immigrant parties and tried to find out whether support was backed by shared political interests (such as 
Table 2. Migrant and German attitudes towards politics and parties

\begin{tabular}{|c|c|c|c|c|c|c|}
\hline & German & Turkish & Ex-Yugo & Greek & Italian & Spanish \\
\hline \multicolumn{7}{|c|}{ a. Political interest by nationality (\%) } \\
\hline Yes & 30.0 & 15.4 & 16.4 & 13.0 & 13.3 & 12.7 \\
\hline No & 70.0 & 84.6 & 83.6 & 87.0 & 86.7 & 87.3 \\
\hline Phi & - & -0.08 & -0.06 & -0.06 & -0.06 & -0.04 \\
\hline Sig. & - & 0.000 & 0.000 & 0.000 & 0.000 & 0.000 \\
\hline$N$ & 11,325 & 781 & 432 & 270 & 361 & 126 \\
\hline \multicolumn{7}{|c|}{ b. Existence of party identification (\%) } \\
\hline Yes & 48.6 & 23.2 & 21.8 & 20.5 & 29.3 & 32.8 \\
\hline No & 51.4 & 76.8 & 78.2 & 79.5 & 70.7 & 67.2 \\
\hline Phi & - & 0.13 & 0.10 & 0.08 & 0.06 & 0.03 \\
\hline Sig. & - & 0.000 & 0.000 & 0.000 & 0.000 & 0.000 \\
\hline$N$ & 10,560 & 742 & 385 & 249 & 304 & 119 \\
\hline \multicolumn{7}{|c|}{ c. Strength of party identification (means) } \\
\hline Mean & 3.35 & 3.14 & 3.33 & 3.11 & 3.26 & 3.26 \\
\hline$t$-value & - & 3.37 & 0.27 & 1.55 & 1.07 & 0.74 \\
\hline Sig. & - & 0.00 & 0.079 & 0.013 & 0.029 & 0.046 \\
\hline$N$ & 4,863 & 148 & 79 & 38 & 81 & 38 \\
\hline
\end{tabular}

Source: GSOEP (1996).

pro-minority rights). We also inquired about interests in homeland versus German politics, ${ }^{7}$ assuming that a strong interest in German politics would render respondents more likely to vote for German parties, whereas a concern with homeland issues would render them more likely to favour an ethnic lobby reflecting homeland cleavages and identities. Finally, we sought to assess how far these attitudes reflect different factors that have been shown to play a role in political participation. Since we cannot analyse migrants' past voting behaviour, we restricted ourselves to collecting evidence about these three basic (and measurable!) forms of immigrant electoral participation, even though other forms of course do exist (for instance, migrants pursuing ethnic issues through host-country parties - see Rath 1988).

\section{Migrants' attitudes towards German parties and politics}

The first question to answer is how far Germans and migrants differ with respect to their political interests and party preferences, and whether these differences can be traced back to differences in individual factors known to influence participation. Alternatively they might be related to migrants' legal exclusion and thus to the institutional environment. Our data (Table 2) indicate, first, that immigrants are generally less interested in politics than Germans; second, that a smaller percentage of this population identifies with a German party; and third, that this identification is fairly weak. According to Table 2, about one-third of all Germans but only about one-sixth of all immigrant groups has a high or a very high interest in German politics. In addition, half of all Germans but only about one-fourth of all immigrants identify with a German political party and those migrants who do so show a weaker identification. This pattern prevails for all but the migrants from former Yugoslavia.

The fact that migrants identify with a German party less often and show a lower political interest than Germans does not necessarily say anything about 
Table 3. Party identifications for the left/right scale (\%)

\begin{tabular}{lccccccc}
\hline & German & Turkish & Ex-Yugo & Greek & Italian & Spanish & Total \\
\hline Left & 52.8 & 87.6 & 69.9 & 76.5 & 88.8 & 87.2 & 55.2 \\
Right & 47.2 & 12.4 & 30.1 & 23.5 & 11.2 & 12.8 & 44.8 \\
Phi & - & 0.12 & 0.04 & 0.05 & 0.09 & 0.06 & \\
Sig. & - & 0.000 & 0.000 & 0.000 & 0.000 & 0.000 & \\
$N$ & 5,064 & 169 & 83 & 51 & 89 & 39 & 5,495 \\
\hline
\end{tabular}

Source: GSOEP (1996).

Note: The variable 'left or right sphere' was based on the question 'party preference identification'. If the respondent had a party preference identification $\mathrm{s} / \mathrm{he}$ was asked which party s/he identifies with. SPD (Social Democrats), the Greens, and the PDS (Socialists) were considered leftist parties. CDU (Christian-Democrats), CSU, FDP (liberals), and the Republicans (extreme right) were considered parties of the right.

the content of their identifications or interests. In order to investigate these, we first consider their identifications for German political parties (see Table 3). Those immigrants who identify with a German party clearly favour one that is left-wing, compared with the expressed preferences of Germans (for a similar finding on naturalised Turks see Wüst 2000). This result, in a way, indicates the 'true essence' of immigrants' often-cited leftist tendencies. The data also indicate, however, that conservative anxieties about immigrants causing a shift in the political power balance towards the left has only limited grounds in reality. Based on current party preferences among immigrants and Germans, the voting proportion would shift to the left by only 2.4 per cent if the former became eligible to vote (compare the 'German' to the 'total' column).

Returning to migrants' low interest in German politics and parties, the question arises as to whether it can be explained by differences in the socio-demographic composition of the groups under consideration. As mentioned above, education is an important indicator for control of participation resources and there is typically a positive correlation between education and political interest. In order to assess how age, sex, and education influence the strength of political interest and party preferences we estimate a simple socio-demographic model using logistic regression to explain the dependent variables under consideration here - political interest and the existence of a party preference. In order to investigate further whether migrants are less involved with politics because they are younger and less educated than Germans, we compute two models that include nationality as an additional independent variable (see Table 4). These analyses show that in both groups under consideration, women are less likely to be interested in politics and less likely to have a preference for a German party than men, and that years of education have a strong positive influence on participation. ${ }^{8}$ However, only for Germans does interest in German politics and parties increase with age.

The total model (pooling Germans and immigrants together) shows that migrants' lack of interest in German politics is not a mere effect of their social and demographic status. It is apparent that nationality - independent of the level of education and demographic background - has a significant effect on the dependent variables under consideration. Even at the same level of education, the probability of being interested in politics is about a third lower for Turks and about half as low for most other nationalities compared with Germans. For all 
Table 4. Effects of sex, age, education and nationality on party identification and political interest (binary logistic regression)

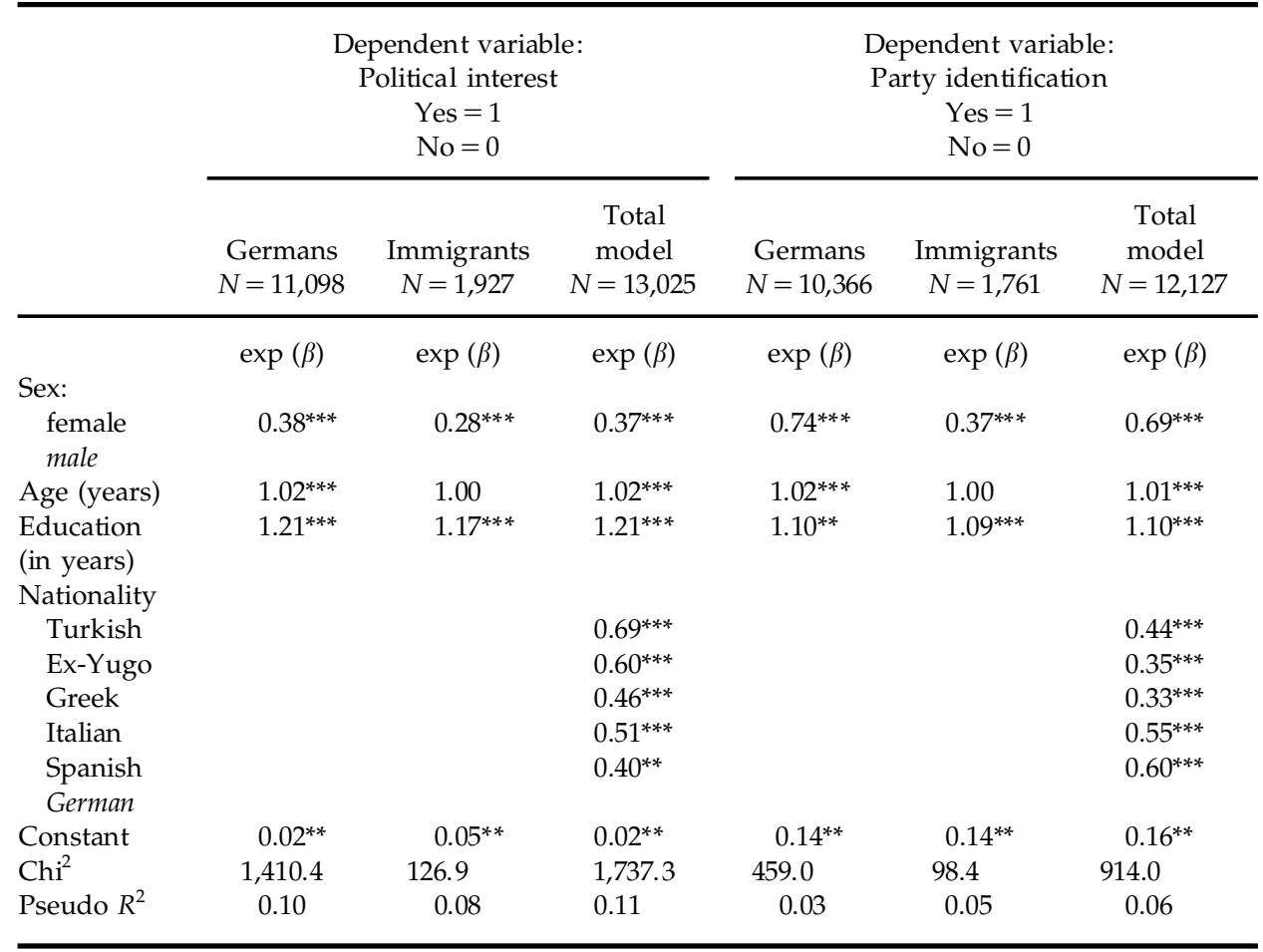

Source: GSOEP (1996).

Notes: ${ }^{* * *} p<0.001,{ }^{* *} p<0.01$; reference categories in italics.

migrant groups under consideration, these results suggest that political exclusion triggers an independent effect among immigrants of political alienation. In other words, the political exclusion of immigrants leads to their demobilisation, at least with respect to the outcomes considered here (political interest and party preference). As the models show, the potential for immigrant political participation is lower than one would expect given their level of educational achievement, although the fit of the models is admittedly not very good, especially the regression on party preference. Obviously variables other than those considered here must play a role as well.

It was argued above that resource-based demobilisation might, under some circumstances, be counterbalanced by group-based mobilisation. Since every fourth Turkish migrant is a member of some club or association, this fairly high degree of self-organisation could positively influence Turkish migrants' involvement in German politics. The fact that Turkish migrants have a higher interest in politics than other nationalities, when other variables are controlled, could reflect their comparatively high degree of internal organisation. We must investigate further to see whether participation per se has an effect, or whether participation in Turkish and in German clubs has a qualitatively different effect. As we have argued, the higher political interest of Turks may not be directed towards Germany, which could explain why it is not accompanied by any preference for a German political party. 
We can investigate these points further, however, by looking at data from the Mannheim Participation Study, which contains information about the relationship between membership in voluntary associations, political interest, and party preference for Turkish migrants. Since we wish to account for the possibility that migrants' political interest is directed toward the homeland rather than the host country, we measured the two forms of political interest separately. ${ }^{9}$ Once again we estimate a simple socio-demographic model first and then include membership in its different forms as additional independent variables.

The logistic regression models shown in Table 5 differ with regard to how membership in a voluntary association is included. The second model measures participation in general; the third participation only in Turkish associations; the fourth participation in German associations; and the fifth model assesses participation in both types of associations. In each model, non-members of the associations under consideration form the reference category.

The socio-demographic modelling set out in Table 5 shows basically the same results as those presented above using the GSOEP data. Being female and less educated makes it less likely that migrants are interested in politics or have a preference for a political party. The estimates also indicate that membership of an association promotes migrants' interest in politics but not a party preference. A more detailed analysis, however, shows that this effect on political interest is caused mostly by a very special group: those migrants who participate in German as well as Turkish associations. Although small numbers $(n=40)$ limit our ability to explore the issue further, this group of migrants is exceptionally well integrated into German society as well as their own ethnic community with regard to education, language skills, and social ties with majority and minority members. They are highly politicised but do not seem to be satisfied with the German parties. Migrants who participate exclusively in German or Turkish associations are neither more - nor less - interested in German politics. Things look a bit different with respect to preference for a German political party. Only membership in German associations furthers this kind of identification with host-country institutions. Obviously membership of German clubs forces migrants to think about which German parties they prefer without necessarily furthering their political interest in general.

In sum, our results do not suggest that membership in ethnic organisations (i.e. high integration within an ethnic group) fosters an interest in host-country politics. Only if migrants are simultaneously involved in Turkish and German associations is political participation increased. These findings contradict the prevailing wisdom that membership in ethnic organisations increases participation and interest in host-country politics. We now turn to the issue of whether migrants' weak involvement with German politics might lead to a strong potential for ethnically based political mobilisation - and what role membership in ethnic organisations might play in this regard.

\section{Migrants' support for immigrant parties}

Considering the low political interest and the weak party preferences of immigrants, it seems likely that active mobilisation by German parties will be necessary to convince newly naturalised immigrants to exercise their political rights. In the absence of such an external mobilisation, immigrants might avoid elections entirely, a risk that is especially high if one considers the low political 
Table 5. Effects of age, sex, education and club membership on Turkish migrants' interest in German politics and parties (binary logistic regression)

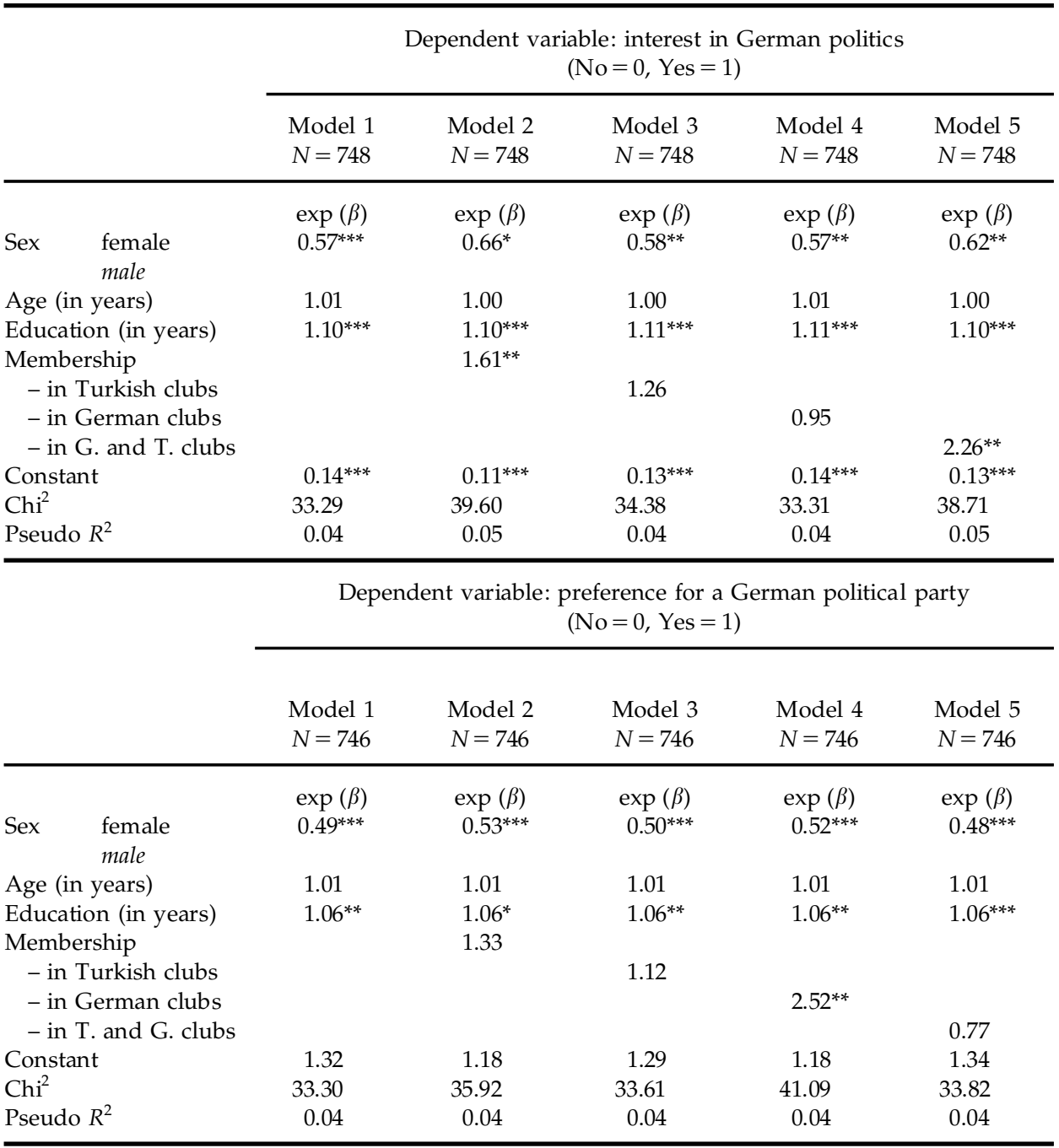

Source: Mannheim Participation Study (1999).

Notes: ${ }^{* * *} p<0.001,{ }^{* *} p<0.01,{ }^{*} p<0.05$; reference categories in italics, for membership see text.

interest of immigrants to begin with. As argued above, immigrants might alternatively favour some sort of ethnic lobby seeking to secure minority or civil rights. To consider the latter possibility, we assessed our respondents' preferences for immigrant parties and the nature of the interests shared by those who supported immigrant parties.

Half of the immigrant respondents (51 per cent) in the Mannheim Participation Study consider immigrant parties rather than German parties to be a more appropriate form of interest representation. ${ }^{10} \mathrm{~A}$ high interest in an ethnically segregated lobby is not, however, sufficient for one to emerge. An important precondition is that migrants share common interests which they do not perceive as being addressed by host-country parties, and that they manage to 
Table 6. Profile of the 'supporters' of immigrant parties (binary logistic regression)

\begin{tabular}{|c|c|c|}
\hline & \multicolumn{2}{|c|}{$\begin{array}{l}\text { Dependent variable: support of immigrant parties } \\
\qquad(\text { No }=0, \text { Yes }=1)\end{array}$} \\
\hline & Model 1: $N=628$ & Model 2: $N=583$ \\
\hline & $\exp (\beta)$ & $\exp (\beta)$ \\
\hline $\begin{array}{l}\text { female } \\
\text { male }\end{array}$ & 1.25 & 1.11 \\
\hline Age (in years) & 1.00 & 1.00 \\
\hline Education (in years) & 0.97 & 1.01 \\
\hline German identity & & 0.87 \\
\hline Turkish identity & & $1.32^{* * *}$ \\
\hline Interest in German politics & & $0.76^{* * *}$ \\
\hline Support of political measures & & 0.97 \\
\hline \multicolumn{3}{|l|}{ Membership } \\
\hline - in Turkish clubs & & 1.17 \\
\hline - in German clubs & & 0.84 \\
\hline - in Turk. and Ger. clubs & & 0.55 \\
\hline - no membership & & \\
\hline Constant & 1.26 & 2.17 \\
\hline $\mathrm{Chi}^{2}$ & 4.47 & 46.74 \\
\hline Pseudo $R^{2}$ & 0.01 & 0.06 \\
\hline
\end{tabular}

Source: Mannheim Participation Study (1999).

Notes: ${ }^{* * *} p<0.001$; reference categories in italics.

organise around these interests. We must therefore determine whether the supporters of immigrant parties and the supporters of German parties differ systematically from each other with respect to political interests.

We first sought to make sure that preferences for immigrant parties are not limited to older labour migrants, whose political socialisation took place in the homeland and would be likely to vanish automatically as the second generation ascends. As before, we begin with a standard socio-demographic model that included age, gender, and years of education regressed on preference for immigrant parties. To assess the degree to which party preference is furthered by mere alienation from host-country politics, in the second model we control for interest in German politics and how much respondents consider themselves to be Turks or Germans. ${ }^{11}$ As indicators of the substantial interests shared by supporters of immigrant parties, we include in the model migrants' interest in political events in Turkey and the extent of their particularistic and universalistic political orientations. We measured the latter by asking respondents about their approval for various distinct political measures directed at immigrants. Some of them were typical civil-rights measures and thus universalistic in nature, others were in support of minority rights and thus particularistic in focus. ${ }^{12}$

The results presented in Table 6 show clearly that the preference for immigrant parties is not limited to a certain socio-demographic group of Turkish migrants, e.g. the older immigrants, but is rather equally distributed throughout the population. But which factors do account for it? Is it a mere reaction among migrants who feel politically alienated from German institutions? Or is it a preference expressed by the subgroup which shares certain substantial interests that are viewed as being ignored by German parties?

The analysis shows that support for an immigrant party is mainly related to 
two factors: migrants' interest in German politics and their ethnic selfidentification. The less interested they are in German politics and the more they identify themselves as Turks the more likely they are to favour immigrant parties. None of the other variables have an effect. This pattern of results suggests that the preference for immigrant parties is a mere reflex of migrants' alienation from the host country. Beyond that, there is no significant difference between the political orientations of those who support German parties and those who support immigrant parties. Immigrants who are in favour of minority rights do not show greater support for immigrant parties than do immigrants who are civil-rights oriented. Moreover, those immigrants who express a strong interest in Turkish political events do not evince a significantly higher preference for ethnically segregated parties. In addition, participation in Turkish associations does not seem to nourish preferences for an ethnic political lobby. Supporters of such a lobby are very heterogeneous with regard to their political interests, which renders the prospects for the successful mobilisation fairly unlikely. In addition, there are no signs that immigrant parties might represent a vehicle for importing homeland-specific political topics and conflicts.

\section{Summary and discussion}

The findings presented above suggest that the political attitudes and behavioural intentions of immigrants are characterised more by apathy than by a potential for ethnic political mobilisation. Owing to their long exclusion from political participation, immigrants' identification with political institutions and political processes in Germany is rather low. Data show that immigrants and Germans differ significantly with regard to their political interests and in the extent of their identification with German parties. The high level of political apathy among immigrants is not a pure effect of their socio-economic background as measured by education, and it is not counterbalanced by participation in ethnic associations, which neither weaken nor further migrants' political interests in Germany, except under very special circumstances. We can thus assume that the political exclusion of immigrants increases the gap between the degree of the political involvement of majority members and that of migrants, which already exists because of differences in the social-structural positioning of these groups.

We find no sign that this lack of involvement in German politics will promote the emergence of immigrant parties once migrants become entitled to vote. Although many immigrants may prefer an ethnically segregated political lobby, this preference is not backed by shared political interests capable of sustaining actual mobilisation. Even if immigrants' low interest in political processes and institutions is accompanied by low confidence in their ability to act as an immigrant lobby, the preference for immigrant parties does not lead automatically to mobilisation in the absence of shared interests and orientations. An estrangement from the political system of the host country seems to be insufficient for the emergence of immigrant parties.

From a more practical viewpoint, our findings suggest that it is by no means certain whether increased opportunities for participation will exaggerate the particularities of immigrants' political attitudes, or whether they will encourage immigrants to adjust their participation patterns to parallel those of natives. Opening up new opportunities for immigrant political participation will certainly not be sufficient to end the oft-lamented democratic deficit, as the case of 
the Netherlands in the mid-1980s has proven (Bukow 1989). In order to increase voter turn-out, Dutch authorities introduced voting rights for migrants at the local level and accompanied them with a massive campaign encouraging migrants to vote. The occasionally high participation rates of Turkish immigrants - in spite of low socio-economic status and a rather low initial interest in politics - contain an important lesson for Germany: neither immigrants' political attitudes nor their behaviour is a matter of fate.

\section{Acknowledgement}

We thank the German Science Foundation for funding this research.

\section{Notes}

1 The term immigrants refers to people of Turkish, Spanish, Greek, etc. citizenship and thus includes people who migrated as well as those who were born in Germany.

2 Press release, Christian Democrat Union, 217/93, Bonn, 15 September 1993.

3 In the GSOEP survey from 1996 a total of 51.4 per cent of all immigrants expressed their interest in staying permanently in Germany. Out of the second-generation interviewees a total of 63 per cent expressed this wish. Persons were defined as second-generation immigrants if they were either born in Germany or if they immigrated to Germany before age 5.

4 Press release, Zentrum für Türkeistudien, 25 November 1999.

5 Several towns have recently reported evidence for this - see Süddeutsche Zeitung, 2 January 2001.

6 Respondents of the GSOEP were asked: (identification) 'Generally speaking, are you inclined to a particular party?' (intensity) 'And how strongly do you support this party?' Respondents of the Mannheim participation study were asked: (preference) 'Do you prefer a certain political party in Germany?' (intensity) 'And how much do you prefer this party?' The intensity was measured by a five-point scale with the extreme values of $5=$ very much and $1=$ very low.

7 In the GSOEP political interest was measured by asking: 'Generally speaking, how interested are you in politics?' using a five-point scale. The response categories 'very much' and 'much' were combined to 'yes' and the categories 'not so much' and 'not at all' were combined to 'no'. Respondents of the Mannheim Participation Study were asked about their interest in the politics of the host country and the country of origin separately. The questions were: 'How interested are you in German politics?', 'How interested are you in Turkish politics?'

8 This relationship can also be found when all groups under consideration are analysed separately. We do not present these results separately because this would take too much space.

9 See note 7 , above.

10 The data for the preference for immigrant parties was collected by asking the following question: 'In some countries where immigrants have the right to vote, special immigrant parties were founded. How do you think immigrants living in Germany could better represent their interests? By voting for German parties or by voting for special immigrant parties?'

11 These data were collected by asking the questions used in the GSOEP: 'How much do you feel like a German?' and 'How much do you feel bound to the country from which your parents originated?' using a five-point scale $(1=$ not at all, $5=$ completely $)$.

12 The respondents were asked to rank six political measures according to their importance. These included civil-rights measures (ease of naturalisation, voting rights, a better supply of German language courses) as well as minority orientated political measures (support for associations promoting the culture of the country of origin, improved possibilities for religious practice, a better supply of Turkish language courses in public schools). Based on this an additive index was constructed by weighting and positioning the measures $(1,2,3$ position) and by multiplying every particularistic measure mentioned by -1 . Thus, the measures-index ranges from $+6=$ strong assimilative orientation to $-6=$ strong segregative orientation.

\section{References}

Alba, R.D., Handl, J. and Müller, W. (1994) 'Ethnische Ungleichheiten im deutschen Bildungssystem', Kölner Zeitschrift für Soziologie und Sozialpsychologie, 46(2): 209-37. 
Bender, S. and Seifert, W. (2000) 'Zur beruflichen und sozialen Integration der in Deutschland lebenden Ausländer', in Alba, R.D., Schmidt, P. and Wasmer, M. (eds) Deutsche und Ausländer: Fremde, Freunde oder Feinde? Empirische Befunde und theoretische Erklärungen. Wiesbaden: Westdeutscher Verlag, 111-46.

Bischoff, D. and Teubner, W. (1992) Zwischen Einbürgerung und Rückkehr. Ausländerpolitik und Ausländerrecht der Bundesrepublik Deutschland. Berlin: Hitit.

Bousetta, H. (2000) 'Institutional theories of immigrant ethnic mobilisation: relevance and limitations', Journal of Ethnic and Migration Studies, 26(2): 229-45.

Brady, H.E., Verba, S. and Schlozman, K.L. (1995) 'Beyond SES: a resource model of political behavior', American Political Science Review, 89(2): 271-94.

Bukow, W.-D. (1989) Ausländerwahlrecht. Cologne: Pahl-Rugenstein.

Cadat, B.-Y. and Fennema, M. (1996) 'Het Zelfbeeld van Amsterdamse Migrantenpolitici in der Jaren Negentig', Amsterdams Sociologisch Tijdschrift, 22(4): 655-80.

Dentler, R.A. (1995) 'The political sociology of the African American situation: Gunnar Myrdal's era and today', Daedalus, 124(1): 15-36.

Diehl, C. (2001) 'Die Partizipationsmuster türkischer Migranten in Deutschland: Ergebnisse einer Gemeindestudie', Zeitschrift für Ausländerrecht und Ausländerpolitik, 21(1): 29-35.

Diehl, C. and Urbahn, J. (1998) Die soziale und politische Partizipation von Zuwanderern in der Bundesrepublik Deutschland. Bonn: Forschungsinstitut der Friedrich-Ebert-Stiftung. Abteilung Arbeits und Sozialforschung.

Fennema, M. and Tillie, J. (1999) 'Political participation and political trust in Amsterdam: civic communities and ethnic networks', Journal of Ethnic and Migration Studies, 25(4): 703-26.

Finkel, S.E. and Muller, E.N. (1998) 'Rational choice and the dynamics of collective political action', American Political Science Review, 92(1): 37-49.

Finkel, S.E., Muller, E.N. and Opp, K.-D. (1989) 'Personal influence, collective rationality, and mass political action', American Political Science Review, 83(3): 885-903.

Ireland, P. (1994) The Policy Challenge of Ethnic Diversity. Immigrant Politics in France and Switzerland. Cambridge, MA: Harvard University Press.

Ireland P. (2000) 'Die politische Partizipation der Einwanderer in Westeuropa: Die Macht der Institutionen', in van Deth, J. and König, T. (eds) Europäische Politikwissenschaft. Ein Blick in die Werkstatt. Frankfurt am Main: Campus, 249-80.

Jones-Correa, M. (1998) 'Different path: gender, immigration and political participation', International Migration Review, 32(2): 326-49.

Koolen, B. (1999) 'Kommunalwahlrecht für Ausländer in den Niederlanden 1990-1998', Zeitschrift für Ausländerrecht und Ausländerpolitik, 19(2): 79-84.

Koopmans, R. and Statham, P. (1999) 'Challenging the liberal nation-state? Postnationalism, multiculturalism and the collective claims making of migrants and ethnic minorities in Britain and Germany', American Journal of Sociology, 105(3): 652-96.

Mehrländer, U., Ascheberg, C. and Ueltzhöffer, J. (1996) Repräsentatiountersuchung 95': Situation der ausländischen Arbeitnehmer und ihrer Familienangehörigen in der Bundesrepublik Deutschland. Berlin, Bonn, Mannheim: Bundesministerium für Arbeit und Sozialforschung.

Mitglieder des Bundesverfassungsgerichts (1991) Entscheidungen des Bundesverfassungsgerichts. Tübingen: J.C.B. Mohr.

Mueller, C.M. (1988) 'The empowerment of women. Polling and the women's voting bloc', in Mueller, C.M. (ed.) The Politics of the Gender Gap. The Social Construction of Political Influence. Newbury Park, CA: Sage, 16-36.

Portes, A. and Rumbaut, R.G. (1996) Immigrant America: A Portrait. Berkeley: University of California Press.

Putnam, R.D. (2000) Bowling Alone: The Collapse and Revival of American Community. New York: Simon \& Schuster.

Rath, J. (1988) 'Mobilization of ethnicity in Dutch politics', in Cross, M. and Entzinger, H. (eds) Lost Illusions: Caribbean Minorities in Britain and the Netherlands. London: Routledge, 267-84.

Sanders, D. (1991) 'Collective rights', Human Rights Quarterly, 13: 368-86.

Sassen-Koob, S. (1979) 'Formal and informal associations: Dominicans and Columbians in New York', International Migration Review, 13(2): 314-32.

Soysal, Y. (1994) Limits of Citizenship. Chicago: University of Chicago Press.

Statham, P. (1999) 'Political mobilisation by minorities in Britain: negative feedback of "Race Relations"?', Journal of Ethnic and Migration Studies, 25(4): 597-626.

Szydlik, M. (1996) 'Ethnische Ungleichheit auf dem Deutschen Arbeitsmarkt', Kölner Zeitschrift für Soziologie und Sozialpsychologie, 48(4): 658-76. 
Tillie, J. (1998) 'Explaining migrant voting behaviour in the Netherlands. Combining the electoral research and ethnic studies perspective', Revue Européenne des Migrations Internationales, 14(2): 71-95.

Togeby, L. (1999) 'Migrants at the polls: an analysis of immigrant and refugee participation in Danish local elections', Journal of Ethnic and Migration Studies, 25(4): 665-84.

Verba, S. (1978) Participation and Political Equality. Cambridge: Cambridge University Press.

Verba, S., Schlozman, K.L. and Brady, H.E. (1995) Voice and Equality: Civic Voluntarism in American Politics. Cambridge, MA: Harvard University Press.

Wüst, A.M. (2000) 'New citizens, new voters? Political preferences and voting intentions amongst naturalized Germans: a case study in progress', International Migration Review, 34(2): 560-7.

\section{Author details}

Claudia Diehl is Research Fellow and Coordinator of the 'Participation of Immigrants' Project at the Mannheim Centre for European Social Research (MZES).

Michael Blohm is a Research Fellow at the Zentrum für Umfragen, Methoden und Analysen (ZUMA), Mannheim.

They may be contacted at the following addresses:

Claudia Diehl

Mannheim Centre for European Social Research (MZES)

Research Departement A

Mannheim University

D-68131 Mannheim

Germany

E-mail: claudia.diehl@mzes.uni-mannheim.de

Michael Blohm

Zentrum für Umfragen, Methoden und Analysen (ZUMA)

Dept. ALLBUS

B 2, 1

D-68159 Mannheim

Germany

E-mail: blohm@zuma-mannheim.de 
Copyright of Journal of Ethnic \& Migration Studies is the property of Routledge and its content may not be copied or emailed to multiple sites or posted to a listserv without the copyright holder's express written permission. However, users may print, download, or email articles for individual use. 